\title{
Diet Diversity and the Declining Importance of Staple Grains
}

\subsection{INTRODUCTION}

Nutrition transition is an important outcome of the structural transformation process (Timmer, 2017). It is understood as the phenomenon that captures changes in households' dietary intake, eating practices and physical activity patterns amidst economy-wide changes (Popkin, 1997). Dietary patterns are influenced by the process of structural transformation in two stages (Pingali \& Khwaja, 2004). During the first stage, economic growth and rise in per capita income induce diet diversification. Consumer preferences move away from quantity to quality, substituting traditional staples with non-staples. In the second stage, the effects of economic globalization are reflected in an increase in the consumption of processed foods which are rich in proteins, sugars and fats. Such structural changes lead to certain improvements in the quality of life, and improved health and hygiene requirements which lead to a decline in the food quantity requirements (Pingali \& Sunder, 2017). At the same time, consumer preference for taste attributes of the food increases and diets begin to diversify. These changing dietary preference demands are met through an expansion of agribusiness value chains and the transformation of food systems.

P. Pingali et al., Transforming Food Systems for a Rising India, Palgrave Studies in Agricultural Economics and Food Policy, https://doi.org/10.1007/978-3-030-14409-8_4 
Nutrition transition in India is increasingly evident. The share of staple grains - rice and wheat-is declining, and households are moving towards a diversified diet (Pingali, 2006). According to the NSSO consumption expenditure surveys, the share of monthly expenditure on cereals and cereal products came down from $41.1 \%$ to $10.8 \%$ in rural India between 1971-72 and 2011-12. For urban areas, cereal expenditure shares declined from $23.4 \%$ to $6.6 \%$. There has been an increase in the share of expenditure of non-staples. Over the next few decades, a rising Indian population, greater urbanization, increases in per capita incomes and demographic changes in the population would create new challenges for food systems.

Agricultural systems would need to respond to the changing demand of the population through more diversified production patterns. Greater income and globalization of diets have led to greater demand for diverse food, produced globally as well as imported from abroad. For a healthy nutrition transition to take place, food systems should have a sufficient supply of nutrient-rich food items and the policy push to promote healthy diets. ${ }^{1}$ While every country goes through this transition along the process of economic development, the nutrition-related health outcomes along the process may vary. In the next chapter, we discuss the changing burden of nutrition and health that takes place during the structural transformation process. Understanding the nature of nutrition transition, and how it shapes and is shaped by the food systems, is essential for public health and nutrition policy.

Building on this thread, this chapter asks the following questions: What is the nature of changing food demand in India as we look towards 2050? What does it imply for the food systems? Do these dietary changes imply better nutritional outcomes? Are these changes contributing to the rising concern of the "triple burden" of malnutrition? These questions are important from the perspective of rising incidence of obesity and noncommunicable diseases. Implicit in this chapter is the assumption that a lack of a healthy workforce and a high incidence of undernourished children will put a limit on a country's future growth trajectory. Given that the future demographic predictions-growing numbers of working-age people entering India's labor force-poor diets and poor health would lead to the loss of the potential returns from this "demographic dividend".

\footnotetext{
${ }^{1}$ In the chapters on agricultural supply, we discuss options for catering to diversified production systems and commercialization of farms so that they can benefit from the growing urban demand for food.
} 


\subsection{The Nature of Changing Food Demand}

By 2021, India is expected to overtake China as the most populous country in the world. With around 1.38 billion people (almost $17 \%$ of the world), changing food habits - dietary quality as well as quantity-have ramifications for future consumption demand and food systems. Westernization of diets and the agri-food system transformation are central to understanding the nature of future demand in India (Pingali, 2007; Reardon \& Timmer, 2014). Traditional food systems and food policy were conceptualized around the emergency response to drought and hunger mitigation, a common feature of the Indian agrarian economy prior to the 1970s. Breakthroughs in grain production technology because of the Green Revolution led to self-sufficiency in food production. Food security concerns therefore evolved from food availability to access. Similarly, rising income because of agricultural productivity growth and its economywide effects facilitated greater demand for the consumption of non-cereals relative to staples. The first stage of India's nutrition transition was completed with the achievement of food self-sufficiency. The challenge of food availability therefore has been addressed. The new challenge lies in the access and affordability of a nutritious diet. With an increase in the demand for high-value agricultural products such as fruits and vegetables, dairy and meat and processed foods, India has now entered the second stage of this nutrition transition. Indian diets are now becoming more westernized, influenced by a multitude of factors such as rising income, demographic transition, urbanization and the spread of retail chains or supermarkets. Urbanization, demographic changes, globalization and exposure to new types of food have not only brought about lifestyle changes but have considerably changed Indian food consumption patterns too.

Consumption data from subsequent rounds of the National Sample Survey (NSS) appropriately reflects these dietary changes (Fig. 4.1). There has been a secular decline in the household share of food expenditure, across both rural and urban areas. In 1972-73, 72.9\% of monthly expenditure was allocated to food items in rural India which has come down to $52.9 \%$ in $2011-12$. The share of food expenditure in urban areas is lower than rural shares and has come down significantly from $64.5 \%$ to 42.6\% during the same time. This is consistent with Engel's Law which states that the proportional share of food expenditure declines in the household budget with growth in income: over time and across income classes. The declining share of food expenditure, however, also reflects the 


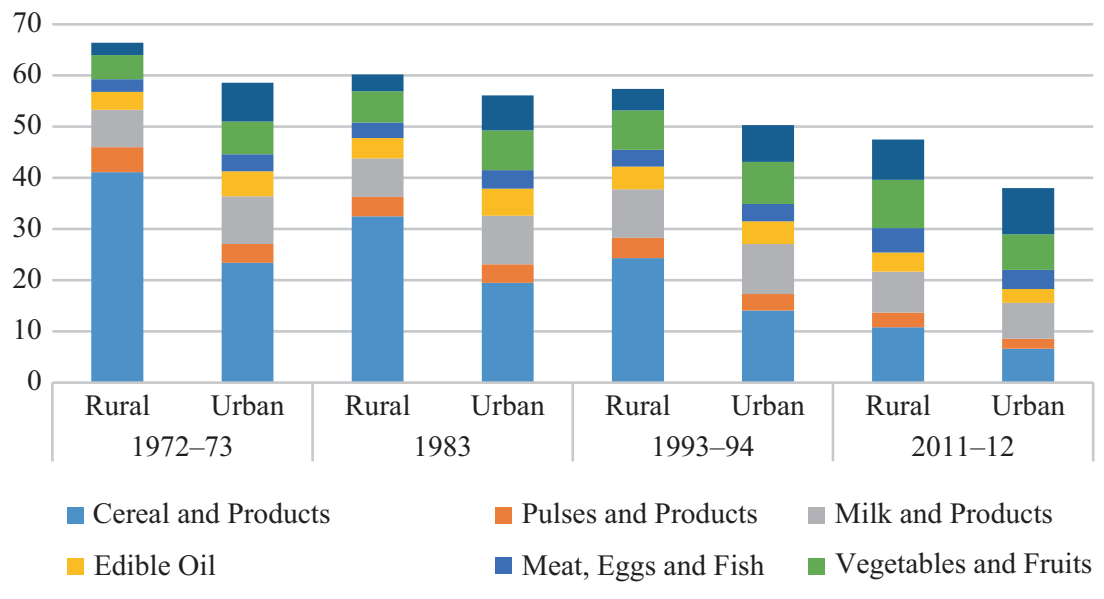

Beverages and Processed Food

Fig. 4.1 Share of monthly expenditures on various food items. Source: NSS Surveys; based on authors calculations

move towards a more diversified diet with an increase in income. This confirms the Bennett's Law which states that lifestyle changes accompanied by the opportunity cost of women's time and urbanization lead to a reduction in the demand of staple food items and hence a proportional share of food expenditures. One can see that the decline in the share of food consumption has been accompanied by a proportionately higher decline in the share of expenditure on cereals, while expenditure on noncereals like vegetables, fruit, dairy products, edible oils, meat products, beverages and other processed food has increased. A compelling case for the changing dietary preferences can be discerned through food expenditure elasticities. These elasticity estimates reflect how an additional increase in household expenditure would be spent on the food. Commodities with higher expenditure elasticities would imply that the consumers would spend an extra unit of income gain on the particular item. Joshi and Kumar (2016) calculate these elasticities which show that consumers prefer an additional income on food and beverages, followed by animal protein items (meats, fish and eggs) (Fig. 4.2). Consumer food preference is the lowest for cereals followed by coarse cereals.

These statistics strongly reflect the notion that India is undergoing a nutrition transition where higher incomes facilitate greater consumption of non-cereal food products, processed food and eating out. The changing 


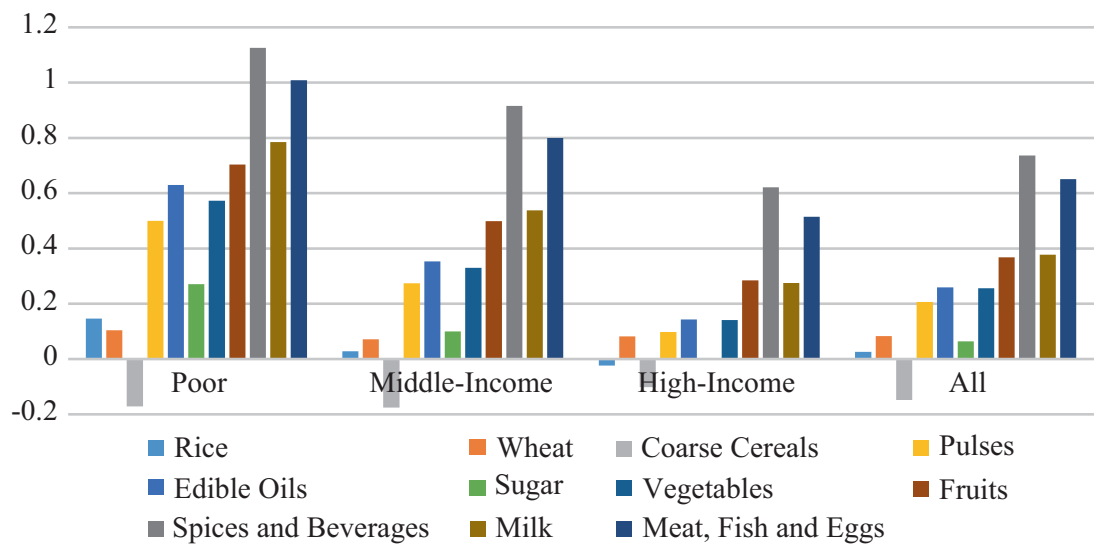

Fig. 4.2 Expenditure elasticity for food items by household class. Source: Joshi and $\operatorname{Kumar}(2016)$

nature of food demand reflects Indian consumers' desire to move away from staple dominated diets. With time, Indian consumers-urban and rural-are moving towards the calorie threshold at which greater income leads to substitution away from cereals. Staples are the cheapest source of calories. They are essential for the diet, especially for the poor, to address hunger. Once households surpass a subsistence level of energy intake, their marginal utility from extra calories declines and they substitute towards food products with non-nutritional attributes such as taste (Jensen \& Miller, 2010). The diversification of diets also comes at a cost. Evidence suggests a preference for variety and quality to increase over time across the entire population distribution, even the poorest households (Rahman, 2017). Greater income and rising monetary value of time use allow households to afford that. Poverty estimates for rural India for the years 2001-12 suggest that districts with a lower incidence of poverty have a greater share of food expenditure on non-cereals compared to cereals (Fig. 4.3). There is also a decline in the dietary practices with a change in poverty levels which leads to a decline in average calorie consumption while overall nutritional and other health outcomes continue to improve. Occupational changes which require less strenuous labor, improvements in health, hygiene and sanitary conditions across India have reduced the need for greater energy intake (Deaton \& Drèze, 2009; Duh \& Spears, 2016). Looking ahead, therefore, one can convincingly argue that consumption demand for these non-staples is expected to drive the future food system. 


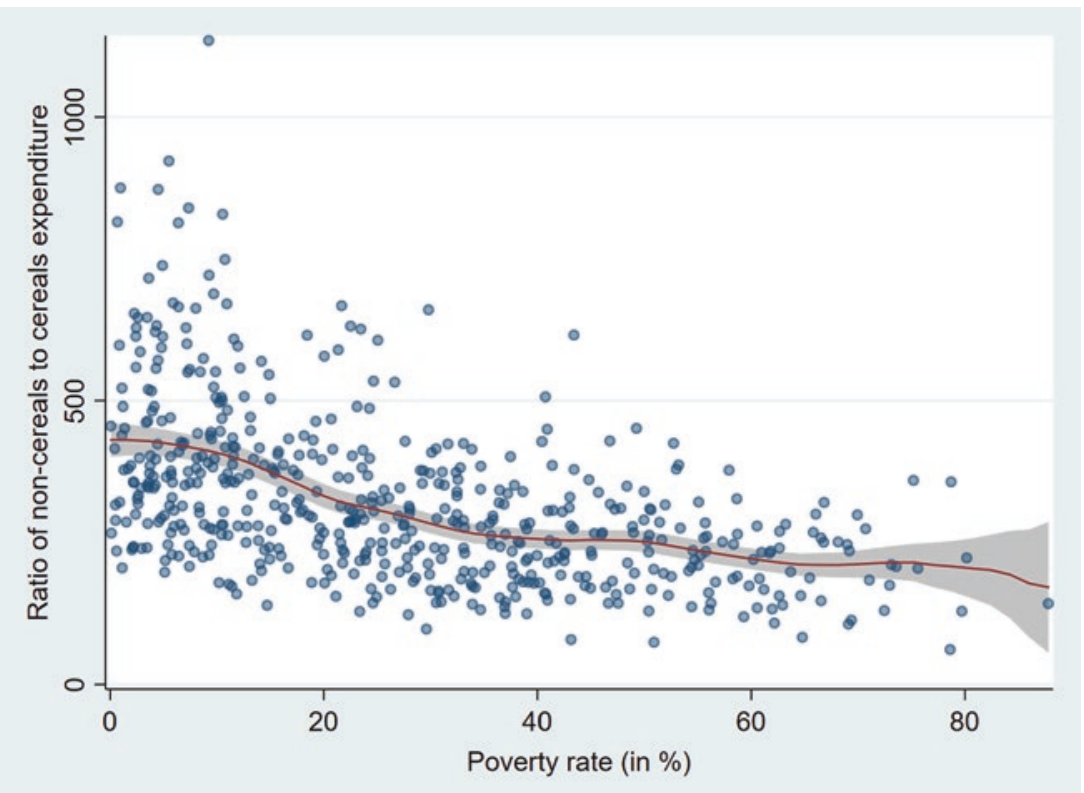

Fig. 4.3 District-level association between share of expenditure on non-cereals to cereals and poverty levels in rural India. Source: NSSO 2011-12; based on authors calculations

\subsection{Transformation in the Agri-food Systems}

Rising demand for high-value products, eating out and processed food has coincided with the growth of restaurants and fast-food chains and the emergence of modern food value chain. Newer forms of food value chains have affected how food travels from farm to fork. The expansion of modern value chains through large modern supermarkets or mega-markets have gradually started replacing small convenience stores, at least in the urban centers. The proliferation of retail chains - of varying quality, tastes and affordability catering to all sections of the society-and changing time use of women, too, have affected how India eats.

Reardon and Timmer (2014) identify five interlinked transformations of the agri-food system occurring across Asia: (1) urbanization, (2) diet change, (3) agri-food system transformation, (4) rural factor market transformation and (5) intensification of farm technology (the agricultural transformation). 
Broader developments in the food system have made the staple grain selfsufficiency paradigm of food security redundant. During the early years of the Green Revolution, "grow more" policy objectives for the rising population disregarded the food supply chain and urban food demand (Reardon \& Timmer, 2014). Almost five decades later, urban food economy has increasingly become important with a greater share of the population living in urban areas and changing dietary patterns of the consumers and greater movement of people and products along the rural-urban continuum. Food growers are now more sensitive to urban food demands. Further, labor mobility from rural to urban areas and the rise in rural incomes have further facilitated the changes in rural dietary patterns. Changing food demand is also characterized by a growing consumer preference for internationally acceptable grades and standards that signal quality and nutritional diversity in food and food products and align with their health, food safety and environmental concerns (Eaton, Meijerink, \& Bijman, 2008; Narayanan, 2014; Poulton, Dorward, \& Kydd, 2010; Roy \& Thorat, 2008; Swinnen \& Maertens, 2007).

One of the key drivers of agri-food systems and future food demand in India is the expansion of the modern food retail industry during the last decade. Market research reports suggest that the number of supermarkets have increased from 500 in 2006 to 8,500 in 2016. With an annual growth of around 15\%, India's food retail industry is ranked as the sixth largest in the world. Currently, it is valued at 380 billion USD (USDA, 2018). It contributes to a substantial part of the overall economic output and has grown because of favorable changes in demographics along with increasing disposable incomes. Much of the retail sector continues to be unorganized, but there has been a significant growth when organized brands were almost non-existent. The emergence of modern retail in India has taken place in three stages (Reardon, Lansing, Minten, \& Ababa, 2011). It began with the expansion of government retail chains during the 1960s/1970s. In the second stage, there was a proliferation of chain of cooperative retail stores starting in the 1970s and 1980s, followed by the rapid increase in the presence of private retail chains beginning slowly in the 1990s which picked up pace during the 2000s. In the last decade, private retail stores have become even more prominent with the advent of Foreign Direct Investment (FDI)

\footnotetext{
${ }^{2}$ https://www.statista.com/statistics/791302/india-number-of-supermarkets. Accessed on November 13, 2018.
} 
in retail. Supermarkets are now spreading across the country. Studies have shown that organized modern retail is growing quite faster than the unorganized retail sector in India. The number of modern retail stores in Delhi, for example, has more than doubled during 2003-09 with the private sector modern retail comprising $6.5 \%$ of the processed food markets and about $3-4 \%$ of the fresh produce (Minten, Reardon, \& Sutradhar, 2010). Comparing these estimates to the value of food and agricultural exports from India, Minten et al. (2010) find the contribution of modern retail to be close to $41 \%$ of this number, which is remarkable given that the Indian food retail market is still in its infancy. Greater penetration of the food retail market in India is also a result of changes in economic and demographic structure: rise in incomes and the emergence of a middle class; urbanization driven by rapid growth small and medium towns, apart from the larger urban metropolis. Greater public infrastructure (roads and communication channels) enabling better rural-urban connectivity; and remittance-based economies and global integration of the economy and people. With FDI in retail being approved, the availability of processed foods would vastly increase, especially catering to the well-off urban population more connected to the global consumption trends and with sufficient disposable income.

Together with the expansion of food retail, there has also been a significant change in how India eats. Entry of foreign brands like McDonald's, Pizza Hut, Domino's and others during the 1990s and greater participation of women in the workforce, at least in the urban areas, eating out is increasingly becoming a common feature. More than $25 \%$ of the households report to eating out every month (Gaiha, Jha, \& Kulkarni, 2013). Quite understandably, people in the major metropolitan cities eat out the most, followed by the urban population in nonmetro urban areas and then by the rural population. With greater urbanization in the future, the eating out feature of the Indian population is further expected to increase. While consumption from local vendors and small eateries has always been a feature of Indian diets, the emergence and consolidation of indigenous brands like Haldiram's and Barbeque Nation, among others, have also affected Indian diets. Greater integration with the global economy, and the rise of an aspirational "middle class" with it, has played its role in bringing this change in consumption patterns, providing an opportunity for the modern agri-food systems to evolve. 


\subsection{Urbanization, Cultural and Demographic Change}

Urbanization and demographic changes have been the key drivers of nutrition transition. The processes of urbanization, changing environments (physical and economic) as well as dietary preferences interact to influence urban diets and nutritional outcomes. According to the Census 2011 figures, $33 \%$ of the Indian population is classified as urban. However, using other methods of urban concentration, the proportion of India's population living in areas with urban-like features stands much higher at $55.3 \%$. According to UN World Urbanization Prospects, India's urban population share would equal that of the middle-income countries by 2050 (Fig. 4.4). Rising population along the peripheries of major metropolitan citiesbeyond the official administrative boundaries of major cities like Delhi, Mumbai, Hyderabad and Kolkata-has led to greater urban agglomeration effects leading to a rising demand for restaurants and other related business opportunities. Overall urbanization rates of India, however, mask the degree of urban food demand. A study by Ablett et al. (2007) finds that by $2006,29 \%$ of India's population lived in cities, yet urban consumers contributed to $43 \%$ of all expenditures on food consumption. As India urbanizes more, future consumer food demand would begin to resemble that of east and southeast Asian countries where urban consumers account for more than two-thirds of overall food expenditures (Reardon, 2015).

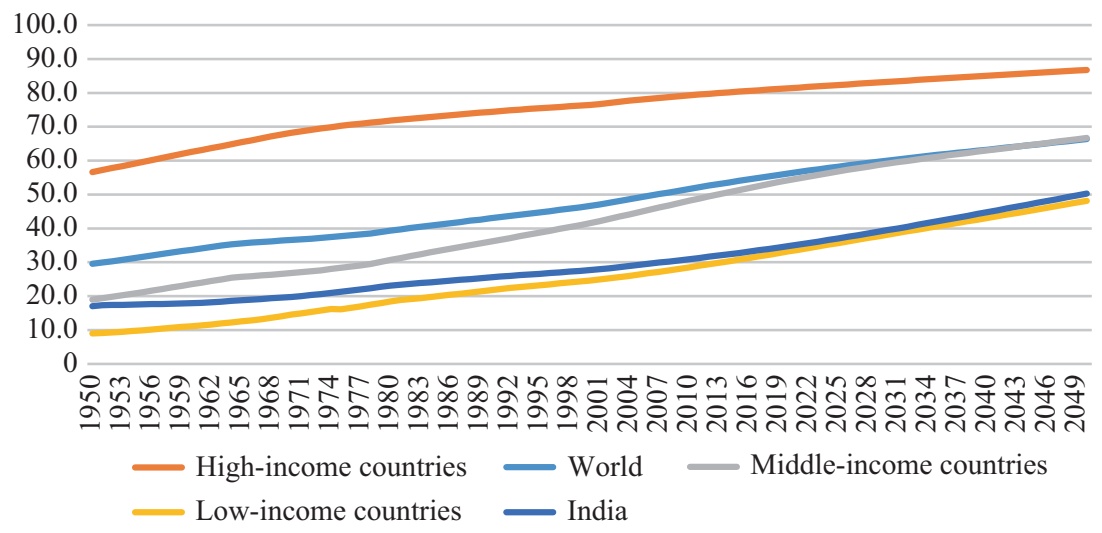

Fig. 4.4 Projected share of urban population. Source: UN World Urbanization Prospects 
A notable feature of India's demographic change is the emergence of a middle class which consists of around 600 million, or half of India's population (Krishnan \& Hatekar, 2017). Multinational corporations have been betting on this rising middle class and emerging consumer economy in India (Ablett et al., 2007). Reduction in poverty and greater consumer demand for food quality is expected to create significant potential growth for the food industry. India's new urban middle class comprising of many single working youths, nuclear families and working couples, travelling internationally and living metropolitan lifestyles, has led to the westernization of food preferences (Pingali \& Khwaja, 2004). Greater frequency of dining out, tasting alternative cuisines and the reliance on ready-to-eat foods reflect the same. This has resulted in a significant increase in the number of restaurants, food courts and internationally branded eateries across India's large cities. The market value of food restaurants in the food service industry has more than trebled in the last decade, from 70.5 to 230.1 billion USD between 2010 and $2019 .^{3}$

Greater migration (domestic and international), cable television and the penetration of the Internet have also played their role in the rising demand for processed food products and the food service industry. Changing dietary practices aren't only restricted to urban areas as greater rates of spatial diffusion of cultural habits have influenced dietary patterns even in rural areas. While the urban elites may emulate western diets, rural population imitates the consumption practices of those in urban areas. ${ }^{4}$ There is also an ongoing process of convergence as well as adaptation of dietary practices across regions (Kennedy, Nantel, \& Shetty, 2004). While convergence refers to greater similarity in diets-decline in staple consumption and increase in the demand for pulses, animal-based proteins and fruits and vegetables-dietary adaptation implies the adjustment of diets to the changing pace of urban lifestyles. In households where both parents often commute long distances and work long hours,

\footnotetext{
${ }^{3}$ https://www.statista.com/statistics/676084/value-of-restaurants-in-food-serviceindustry-india/. Accessed on November 13, 2018.

${ }^{4}$ Government statistics on food consumed away from home (FAFH) is often underreported (Smith, 2015). Consumption expenditure surveys conducted by the National Sample Survey Organization (NSSO) of India collect information on the quantity consumed and expenditure incurred on a set of food items. Earlier they collected information on the consumption of "cooked meals" as a single item in their food consumption module which aimed to capture FAFH at the household level. It is only recently that they have moved to more detailed FAFH sub-categories to capture the prevalence of eating out.
} 
consumers eat more meals outside the home and purchase more brandname processed foods. Time constraints arising from the greater participation of women-primarily responsible for cooking at home-in the household reliance on purchased or packaged processed food have further seen an increase.

\subsection{Concerns for the Food Systems}

While the changing food demand is suggestive of the nutrition transition and offers the potential for growth of the agribusiness industry and ushering in the modern food value chains, it also poses a challenge for the food systems regarding what is produced and consumed and ultimately its effect on human health. Greater diversification of the food consumption basket-because of increase in the consumption of processed and packaged food, away-from-home meals, edible oils and sugar-sweetened beverages - has led to concerns of a high incidence of obesity and other non-communicable diseases. While over-nutrition has increased, average calorie consumption has declined. With the changing nature of occupations, better means of transportation and mechanization of agriculture, there has been a reduction in physical activity and the advent of a more sedentary lifestyle among the working-class population. Changes in lifestyle along with an improvement in disease environment have led to a lowering of the total energy intake (Deaton \& Drèze, 2009). Reduction in calorie requirements, however, has coincided with a rise in the quality of diets as measured through dietary diversity (Shankar et al., 2017). On average, the number of food groups consumed by the households increased from 8.8 (out of 12 food groups) to 9.7 between 1990 and 2012 in rural India. In urban areas, it increased from 9.3 to 9.5 groups. Per capita calorie intake declined by $8.6 \%$ and $2.4 \%$ during $1983-2005$ in rural and urban areas, respectively.

\subsubsection{Rise in the Consumption of Convenience Food}

Since the 1990s, there has been a greater shift towards the consumption of "convenience food" as eating out has increased along with the greater consumption of processed food, beverages and other packaged items which have higher salt, fat or sugar content, often associated with the incidence of chronic non-communicable diseases (NCDs). The consumption of these unhealthy commodities is rapidly rising across most low- and medium-income countries 
(LMICs) because of greater availability and access. Understanding these transformations along with economic and social changes is important to understand future food demand. With the increase in the money value of time as wages rise, more and more women participate in the workforce, and convenience food not only becomes affordable but also frees up time. The issue of energy-dense snack items high in fat content is now increasingly becoming a feature of household consumption in low-income populations across rural and urban areas. Consider the following passage from a news article about slums in New Delhi:

\begin{abstract}
... "Most children have tea and phan [rusk] for breakfast," said Najma, a feisty worker who went door to door to conduct the study. "Mothers have to leave early on work so they give the babies what they eat." Food is cooked twice at home: rice, roti, dal [mostly masoor since it's the cheapest], sabzi [mostly potatoes], but never green leafy vegetables or fruit or milk. Meals are interspersed with Maggi, popcorn and a variety of chips, which kill the appetite for a full meal. It isn't just that children like their taste, there is an economic rationale to rely on junk food. A packet of Maggi noodles costs $R s 10$ while a meal of rice, dal and vegetables would cost approximately three times that amount. (Mohan, 2015)
\end{abstract}

The cost of food from the local carts and other cheap processed food is often less than the cost of cooking food at home, especially when both parents work. Consumption of these unhealthy food items, in an increasingly dynamic economy, is often an economic choice for the poor. Even in rural India, the consumption of convenience foods like chips, chocolate, bakery products, soft drinks and other sugar-sweetened beverages is extremely common among school-going children (Gupta, Downs, Ghosh-Jerath, Lock, \& Singh, 2016). With $60 \%$ of India's population under 30 years of age and many of them on the move, various formal and informal retail food sellers provide eating convenience food options. There has been a steady expansion of restaurants and fast-food eating joints in India. Many global brands have opened up their retail chains in India, specifically focusing on the younger section of India's population. Based upon a household survey of slums in Delhi, Singh, Gupta, Ghosh, Lock, and Ghosh-Jerath (2015) find that on average households spend around 11\% of their monthly food expenditure on snacks, while $15 \%$ of the working member reported eating lunch outside. While higher-income households may rely on more packaged convenience foods, for the households with poor socioeconomic, often the local vendors are the purchase point. Food hygiene and dietary safety, therefore, become very pertinent concerning diets of the poor. From the policy perspective, 
these changes are often ignored as food consumption from hawkers, and wet market stall operators are not appropriately captured in the NSSO surveys used to estimate dietary patterns (Smith, 2015).

\subsubsection{Food Prices and Inflation}

A major concern, which affects food security and dietary diversification, especially for the poor, is the rise in food prices. Food inflation is among one of the most pressing challenges for India's food policy as higher levels of inflation have been a feature of the economy in the last decade. Rise in food prices directly affect the diets and nutritional status of households (Brinkman, de Pee, Sanogo, Subran, \& Bloem, 2010). In India, the food price inflation episode between 2006 and 2009 led to an increase in the risk of child malnutrition (Vellakkal et al., 2015). This connection stems from a decline in the quantity of food consumed and dietary quality through an increase in the cost of the food basket. With a clear shift, away from cereals, it is important to ensure other nutritive food items are available at affordable prices. Without access to nutritive substitutes, dietary diversity would suffer. Protein-rich items such as pulses and animal-based protein items have seen an increase in the prices as well as its volatility (Fig. 4.5). This was famously referred to as "protein inflation" by the former deputy

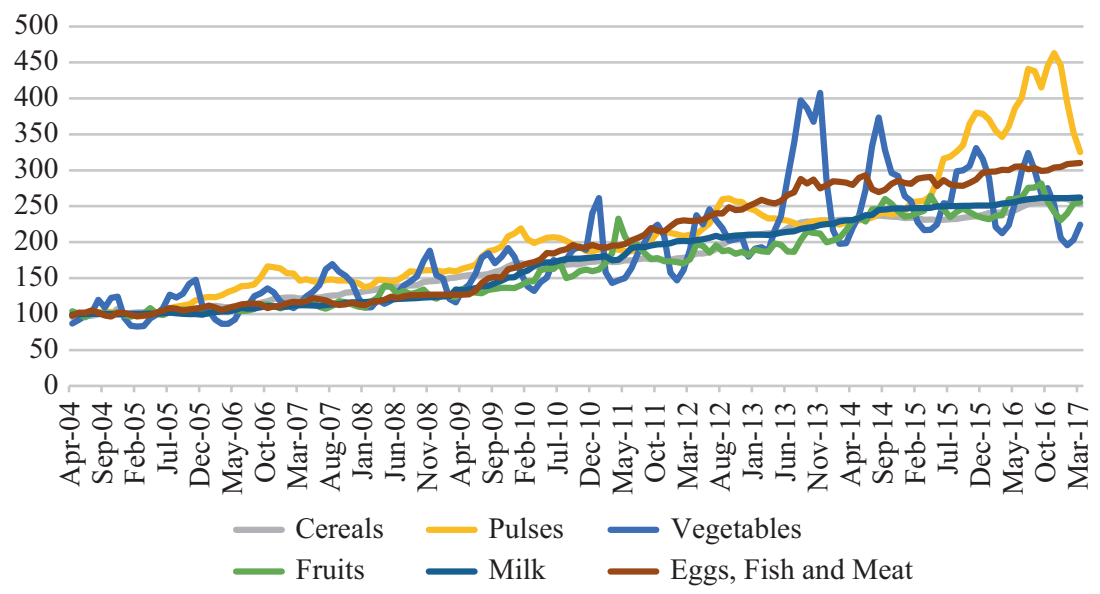

Fig. 4.5 Wholesale Price Index (WPI) for food items. Source: Office of the Economic Adviser, Govt. of India, Ministry of Commerce and Industry 
governor of India's central bank (Gokarn, 2011). Increase in the price of protein-rich items like eggs, meat, fish, milk is primarily driven by greater demand for these products (Sekhar, Roy, \& Bhatt, 2017). Similarly, the highly seasonal supply of fruits and vegetables and the lack of a storage infrastructure to smoothen prices make effective food price policy and, hence, become tantamount to a nutrition-sensitive food system which enables transition towards a healthier diet.

\subsubsection{Implications for Health, Nutrition and Environment}

While greater dietary diversity has been welfare enhancing, the consumption of more protein and fats together with a decline in the levels of physical activity as a result of urbanization and changes in occupational patterns have led to the greater prevalence of obesity, coronary heart disease, diabetes and other non-communicable diseases among the Indian population. According to an estimate by Misra et al. (2011), nutrition transition has led to an "epidemic of diet-related non-communicable diseases (DR-NCDs)" which begins with maternal nutritional deprivation causing low birth weight among infants, “... which, coupled with early childhood 'catch-up growth', leads to obesity in early childhood, thus predisposing to NCDs later in life". This raises an important challenge from the public health perspective. There are distinct regional patterns in diets which have implications for the various aspects of NCDs. As one moves from rural to urban areas, there is an increase in energy and salt consumption, but the share of calories from rice declines, while the share of oils, fruit, pulses and legumes increases (Joy et al., 2017). This suggests that while urban consumers had a greater likelihood of being obese, they are less likely to be underweight. Their study suggests beneficial as well as detrimental impact of diets on health because of dietary changes in India.

\subsection{Conclusion}

Indian diets are changing. While this nutrition transition may be slower compared to other developing countries like China or those in Latin America, the influence of the forces of globalization on Indian dietary habits cannot be denied. Urbanization and globalization have enabled easier access to fat and sugar-rich food items which appeal to the innate sensory preferences. Changing consumer preferences-driven by income growth, demographic changes and globalization effects-for more diversified foods have increased the demand for foods other than staples. 
Accelerated nutrition transition for the low-income countries, however, may not be beneficial if the supply of healthy food items is absent from the food value chain (Drewnowski \& Popkin, 2009). The traditional notion of more developed countries as the only ones with fat-rich diets is no longer true. Across the developing world, there has been a decline in the importance of cereals, while consumption of animal-based protein, and processed, and purchased food is on the increase. These trends are consistent across rural as well as urban areas, though the degree of transition may vary. Demand-side challenges for food security in India need to factor in these changes. Policy debates around food security in India till now have mainly focused upon ensuring adequate access to calories through a continued focus on staplegrain production. However, emerging trends around dietary changes and nutrition transition provide a compelling case for questioning the existing paradigm and opening up conversations around access to good quality, and balanced diet. In order to bring a more nutritious and diverse food system, accessibility and affordability aspects of food security needs to be stressed. Creating new opportunities for the food systems to augment supply of more nutritious food for this changing demand should thus become a policy focus.

While modern food retail in India is still in its infancy, it is already expanding rapidly, at least in urban areas. With greater rural infrastructure and purchasing power, it is expected to penetrate rural areas soon. An emerging policy challenge is the rising consumption of packaged/ processed food and the growing phenomena of eating out. Increases in the rates of obesity and overweight are widely documented, from urban and rural areas in the poorest countries of sub-Saharan Africa and South Asia to populations in countries with higher income levels. While these are some of the manifestations of nutrition transition, its ill-effects regarding the rising incidence of NCDs need to be actively managed. Modernizing supply chains, better food safety standards and incentives for encouraging a more health-oriented food industry would be a crucial step towards that. While saying this, we are fully aware of the issue of the acute levels of undernutrition in India. We do not intend to gloss over this aspect of malnutrition and the consumer demand from the lower end of the income strata. What we argue is for a more nutrition-sensitive food system which addresses the issue of undernutrition as well as obesity. The long-term policy challenge lies in enabling a diversified food system where a better and more diversified diet becomes affordable to all sections of the society.

In addition to the nutritional challenges for food demand, greater competition for land, water, and energy, its related environmental costs pose 
critical challenges for the food systems to supply affordable and nutritious food (Godfray et al., 2010). Similarly, urbanization which is considered as a harbinger of nutrition transition also poses challenges regarding diet quality and over-nutrition. The "messy" nature of urbanization is reflected in the fact that 65.5 million Indians live in urban slums according to Census 2011, and $13.7 \%$ of the urban population lives below the official poverty line. Greater concentration of poor in the urban areas, often with poor access to infrastructure and services, is further expected to impose challenges on the food system. Policy should therefore factor in the dynamic nature of growth and the changing nature of consumer demand for nutritious food systems.

\section{REFERENCES}

Ablett, J., Baijal, A., Beinhocker, E., Bose, A., Farrell, D., Gersch, U., ... Gupta, S. (2007). The 'Bird of Gold': The rise of India's consumer market. San Francisco: McKinsey Global Institute.

Brinkman, H.-J., de Pee, S., Sanogo, I., Subran, L., \& Bloem, M. W. (2010). High food prices and the global financial crisis have reduced access to nutritious food and worsened nutritional status and health. The Journal of Nutrition, 140(1), 153S-161S. https://doi.org/10.3945/jn.109.110767

Deaton, A., \& Drèze, J. (2009). Food and nutrition in India: Facts and interpretations. Economic and Political Weekly, 47(7), 42-65. https://doi.org/ $10.2307 / 40278509$

Drewnowski, A., \& Popkin, B. M. (2009). The nutrition transition: New trends in the global diet. Nutrition Reviews, 55(2), 31-43. https://doi.org/10.1111/ j.1753-4887.1997.tb01593.x

Duh, J., \& Spears, D. (2016). Health and hunger: Disease, energy needs, and the Indian calorie consumption puzzle. The Economic Journal, 1-32. https://doi. org/10.1111/ecoj.12417

Eaton, D., Meijerink, G., \& Bijman, J. (2008). Understanding institutional arrangements-Fresh fruit and vegetable value chains in East Africa. Markets, Chains and Sustainable Development Strategy and Policy Paper No. XX.

Gaiha, R., Jha, R., \& Kulkarni, V. S. (2013). How pervasive is eating out in India? Journal of Asian and African Studies, 48(3), 370-386. https://doi. org/10.1177/0021909612472040

Godfray, H. C. J., Beddington, J. R., Crute, I. R., Haddad, L., Lawrence, D., Muir, J. F., ... Toulmin, C. (2010). Food security: The challenge of feeding 9 billion people. Science, 327(5967), 812-818. https://doi.org/10.1126/ science. 1185383 
Gokarn, S. (2011). The price of protein. Macroeconomics and Finance in Emerging Market Economies, 4(2), 327-335. https://doi.org/10.1080/17520843. 2011.593908

Gupta, V., Downs, S. M., Ghosh-Jerath, S., Lock, K., \& Singh, A. (2016). Unhealthy fat in street and snack foods in low-socioeconomic settings in India: A case study of the food environments of rural villages and an urban slum. Journal of Nutrition Education and Behavior, 48(4), 269-279.el. https://doi. org/10.1016/j.jneb.2015.11.006

Jensen, R. T., \& Miller, N. H. (2010). A revealed preference approach to measuring hunger and undernutrition (No. 16555). In Intergovernmental Panel on Climate Change (Ed.), NBER Working Paper Series. Cambridge, UK: Cambridge University Press.

Joshi, P., \& Kumar, P. (2016). Food demand and supply projections to 2030: India. In F. Brouwer \& P. K. Joshi (Eds.), International trade and food security: The future of Indian agriculture, Part 2 (pp. 29-63). CABI Publishing.

Joy, E. J., Green, R., Agrawal, S., Aleksandrowicz, L., Bowen, L., Kinra, S., ... Dangour, A. D. (2017). Dietary patterns and non-communicable disease risk in Indian adults: Secondary analysis of Indian Migration Study data. Public Health Nutrition, 20, 1-10. https://doi.org/10.1017/S1368980017000416

Kennedy, G., Nantel, G., \& Shetty, P. (2004). Globalization of food systems in developing countries: Impact on food security and nutrition. FAO.

Krishnan, S., \& Hatekar, N. (2017). Rise of the new middle class in India and its changing structure. Economic and Political Weekly, 52(22), 40-48. Retrieved from https://www.epw.in/journal/2017/22/special-articles/rise-new-middleclass-india-and-its-changing-structure.html

Minten, B., Reardon, T., \& Sutradhar, R. (2010). Food prices and modern retail: The case of Delhi. World Development, 38(12), 1775-1787. https://doi. org/10.1016/j.worlddev.2010.04.002

Misra, A., Singhal, N., Sivakumar, B., Bhagat, N., Jaiswal, A., \& Khurana, L. (2011). Nutrition transition in India: Secular trends in dietary intake and their relationship to diet-related non-communicable diseases. Journal of Diabetes, 3(4), 278-292. https://doi.org/10.1111/j.1753-0407.2011.00139.x

Mohan, S. (2015, June 1). Junk food is feeding a malnutrition epidemic in Delhi's slums. Scroll. Retrieved from https://scroll.in/article/728525/junk-food-isfeeding-a-malnutrition-epidemic-in-delhis-slums

Narayanan, S. (2014a). Profits from participation in high value agriculture: Evidence of heterogeneous benefits in contract farming schemes in Southern India. Food Policy, 44, 142-157. https://doi.org/10.1016/j.foodpol. 2013.10.010

Pingali, P. (2006). Westernization of Asian diets and the transformation of food systems: Implications for research and policy. Food Policy, 32(3), 281-298. https://doi.org/10.1016/j.foodpol.2006.08.001 
Pingali, P. (2007). Westernization of Asian diets and the transformation of food systems: Implications for research and policy. Food Policy, 32(3), 281-298. https://doi.org/10.1016/j.foodpol.2006.08.001

Pingali, P., \& Khwaja, Y. (2004). Globalisation of Indian diets and the transformation of food supply systems. Citeseer.

Pingali, P., \& Sunder, N. (2017). Transitioning toward nutrition-sensitive food systems in developing countries. Annual Review of Resource Economics, 9(1), 439-459. https://doi.org/10.1146/annurev-resource-100516-053552

Popkin, B. M. (1997). The nutrition transition and its health implications in lower-income countries. Public Health Nutrition, 1(1), 5-21.

Poulton, C., Dorward, A., \& Kydd, J. (2010). The future of small farms: New directions for services, institutions, and intermediation. World Development, 38(10), 1413-1428. https://doi.org/10.1016/j.worlddev.2009.06.009

Rahman, A. (2017). Food elasticity estimates for rural India: Preference for food variety and between group substitutions.

Reardon, T. (2015). The hidden middle: The quiet revolution in the midstream of agrifood value chains in developing countries. Oxford Review of Economic Policy, 31(1), 45-63. https://doi.org/10.1093/oxrep/grv011

Reardon, T., Lansing, E., Minten, B., \& Ababa, A. (2011). Surprised by supermarkets: Diffusion of modern food retail in India. Journal of Agribusiness in Developing and Emerging Economies, 1(2), 134-161. https://doi. org/10.1108/JADEE-10-2013-0040

Reardon, T., \& Timmer, C. P. (2014). Five inter-linked transformations in the Asian agrifood economy: Food security implications. Global Food Security, 3(2), 108-117. https://doi.org/10.1016/j.gfs.2014.02.001

Roy, D., \& Thorat, A. (2008). Success in high value horticultural export markets for the small farmers: The case of Mahagrapes in India. World Development, 36, 1874-1890.

Sekhar, C. S. C., Roy, D., \& Bhatt, Y. (2017). Food inflation and food price volatility in India: Trends and determinants. IFPRI Discussion Papers, International Food Policy Research Institute (IFPRI). Retrieved from https://econpapers. repec.org/RePEc:fpr:ifprid:1640

Shankar, B., Agrawal, S., Beaudreault, A. R., Avula, L., Martorell, R., Osendarp, S., ... Mclean, M. S. (2017). Dietary and nutritional change in India: Implications for strategies, policies, and interventions. Annals of the New York Academy of Sciences, 1395(1), 49-59. https://doi.org/10.1111/nyas.13324

Singh, A., Gupta, V., Ghosh, A., Lock, K., \& Ghosh-Jerath, S. (2015). Quantitative estimates of dietary intake with special emphasis on snacking pattern and nutritional status of free living adults in urban slums of Delhi: Impact of nutrition transition. BMC Nutrition, 1(1), 22. https://doi.org/10.1186/ s40795-015-0018-6 
Smith, L. C. (2015). The great Indian calorie debate: Explaining rising undernourishment during India's rapid economic growth. Food Policy, 50, 53-67. https://doi.org/10.1016/j.foodpol.2014.10.011

Swinnen, J. F. M., \& Maertens, M. (2007). Globalization, privatization, and vertical coordination in food value chains in developing and transition countries. Agricultural Economics, 37, 89-102. https://doi.org/10.1111/ j.1574-0862.2007.00237.x

Timmer, C. P. (2017). Food security, structural transformation, markets and government policy. Asia and the Pacific Policy Studies, 4(1), 4-19. https://doi. org/10.1002/app5.161

USDA. (2018). GAIN Report No. IN8081. Retrieved from https://gain.fas. usda.gov/Recent\%20GAIN\%20Publications/Retail\%20Foods_New\%20 Delhi_India_6-28-2018.pdf

Vellakkal, S., Fledderjohann, J., Basu, S., Agrawal, S., Ebrahim, S., Campbell, O., ... Stuckler, D. (2015). Food price spikes are associated with increased malnutrition among children in Andhra Pradesh, India. The Journal of Nutrition, 145(8), 1942-1949. https://doi.org/10.3945/jn.115.211250

Open Access This chapter is licensed under the terms of the Creative Commons Attribution 4.0 International License (http://creativecommons.org/licenses/ by $/ 4.0 /$ ), which permits use, sharing, adaptation, distribution and reproduction in any medium or format, as long as you give appropriate credit to the original author(s) and the source, provide a link to the Creative Commons licence and indicate if changes were made.

The images or other third party material in this chapter are included in the chapter's Creative Commons licence, unless indicated otherwise in a credit line to the material. If material is not included in the chapter's Creative Commons licence and your intended use is not permitted by statutory regulation or exceeds the permitted use, you will need to obtain permission directly from the copyright holder.

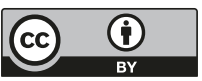

